\title{
CONTOURS OF PACIFICISM:
} RAMSDEN BALMFORTH'S ADVOCACY OF PEACE IN THE UNION OF SOUTH AFRICA AND BEYOND

\section{ABSTRACT}

Among the many dimensions of Christian pacifism in South Africa which remain underexplored is the ministry of the Unitarian minister Ramsden Balmforth (18611941). For approximately four decades beginning shortly after his arrival in Cape Town in 1897, this Christian socialist devoted part of his time to efforts to promote peace both in southern Africa and on a broader, almost global, scale. It is argued that Balmforth was not at any time an absolute pacifist, and that the distinction between "pacifism" and "pacificism" which was advanced by inter alia the British historians A.J.P. Taylor and Martin Ceadel is particularly useful for interpreting Balmforth and placing him on the spectrum of positions with regard to the ethical defensibility of taking up arms.

\section{INTRODUCTION}

The Unitarian minister Ramsden Balmforth (1861-1941) played a much greater role in South African religious and intellectual history than he has in historiography. Beginning shortly after he arrived in Cape Town in 1897 to occupy the pulpit of its Free Protestant Church (which would later call itself "Unitarian"), a position he would hold with only brief respites for four decades, this Christian socialist from Yorkshire wore many hats. In addition to his ministry in Hout Street (the core of which was his preaching on Sunday evenings), he wrote more than a dozen books about theological and literary topics and contributed articles to the daily and religious press as well as scholarly journals in South Africa, the United Kingdom, and the United States of America. In his publications, he

Dr. Frederick Hale, North-West University, Potchefstroom, South Africa. E-mail: fh243@cam.ac.uk 
made noteworthy contributions especially in the fields of Biblical studies, Christian social ethics, and what would subsequently be called "religion and literature". Balmforth also served on various civic committees and played an active part in such organisations as the South African Peace and Reconciliation Society and the Cape Fabian Society. For his efforts, he gained considerable recognition in his second homeland as well as the country of his birth. Editor John Cope of the liberal Johannesburg weekly review The Forum assured readers, arguably too optimistically, in 1942 that "Ramsden Balmforth will long be remembered in Cape Town and, indeed, in South Africa, as a pioneer of progressive thought" (The Forum 1942:5). No less generously, Justice Albert van der Sandt Centlivres eulogised him before a large audience at his memorial service as "a powerful force for good, not only in the Church, but in the land of his adoption. He was a 'citizen of the world'." This fellow Unitarian called attention to the compass of Balmforth's concerns: "Believing all men to be the children of God, he was always the champion of the poor, the oppressed and the suffering, and an earnest seeker after truth. His teachings were a rich spiritual legacy which would be imperishable" (Free Protestant (Unitarian) Church 1942:5). Particularly noteworthy and memorable to some observers who knew Balmforth was his opposition to war and other forms of violence. Immediately after his death, the writer of the "Talk at the Tavern of the Seas" column in The Cape Argus noted that "in the last war he was a pacifist, but no man loathed Nazism more than this gentle, tense man" (The Cape Argus 1942:2).

That Balmforth campaigned indefatigably for peace was well known to many other South Africans. However, the conceptualisation of "pacifism" to cover a variety of ideological and ethical positions may conceal more than it reveals about this Unitarian socialist's attitudes towards war and how he believed it could be averted. Balmforth was not an absolute pacifist, i.e. one who categorically rejected the use of military means by the state and refused to resist violence. Rather, he was an exemplar of what the Oxford historian A.J.P. Taylor called "pacificism" and used to refer campaigning determinedly for peace rather than endorsing armed solutions to conflict (Taylor 1957:59). Fundamental ideational and metaethical differences distinguishing it from "pacifism" were analysed at length by Martin Ceadel's ground-breaking study, Pacifism in Britain 19141945: The Defining of a Faith (Ceadel 1980).

In a previous article, the present writer explored how shortly after disembarking in Cape Town Balmforth became a local leader in efforts to prevent what became the Second Anglo-Boer War (Hale 2001:97-112). The present study will examine a representative sample his writings during the years after the founding of the Union of South Africa in 1910 to highlight 
especially how his endeavours to promote peace were informed by his liberal understanding of Christian ethics and by his life-long commitment to evolutionary socialism. Particular attention is thus paid to Balmforth's opposition to military conscription, his response to the First World War, his advocacy of what would become the League of Nations, his criticism of the Bulhoek Massacre of 1921, his continuing endorsement of the League of Nations despite widespread disillusionment with its ineffectiveness during the 1930s, and his ultimate approval of the Allied campaign against the aggressive foreign policy of the Third Reich. It will also be argued that Balmforth's understanding of how an international organisation for resolving conflicts harmonised with the vision of the League of Nations Union, a British association founded in 1918 whose membership crested at over 400000 in 1931 (Donalds 1981). Its adherents clung to the hope that the League could serve as an effective instrument for averting war even after it had proven its ineffectiveness in halting Mussolini's invasion of Abyssinia and the Spanish Civil War in the latter half of the 1930s.

\section{OPPOSITION TO CONSCRIPTION}

After the constituting of the Union of South Africa, one of the first issues rotating around the axis of militarism was the South African Defence Act of 1912. Balmforth is not known to have played a prominent role in the public debate about that pending legislation, even though he had been then in Cape Town for nearly fifteen years and had already gained a public profile that extended beyond his small congregation. For that matter, the bill's section on conscription does not appear to have been extensively opposed on specifically Christian grounds, although it was indicted from some pulpits. To cite but one example, the eminent Baptist minister Joseph J. Doke of Central Baptist Church in Johannesburg, who had earlier gained local notoriety by sheltering the young activist Mohandas K. Gandhi (about whom he wrote a book), used the pages of The South African Baptist to rail against the proposed law. He attacked it not on explicitly Biblical grounds or on the basis of pacifism but on the venerable Baptist principle of freedom of conscience. He declared that the statute might be more aptly called "A Bill for establishing military despotism in South Africa". Whatever the need for armed forces may be, Doke argued, it was vital to maintain "the inalienable right of the citizen to decide great moral and religious questions for himself". Conscription ipso facto eroded or negated that right (Doke 1912:60).

This dovetailed perfectly with Balmforth's views. As another exponent of the English "Nonconformist conscience", this transplanted Unitarian wrote less than three years later that he had been "one of the few to 
protest at the time it was passed". During the First World War, he looked back at that statute and, in full harmony with Doke's case against it, lamented that it "departs from the sound British principle of voluntary service". It seemed patently unjust to Balmforth that any South African citizen "may be compelled to take up arms in a war or a military expedition which he believes to be unnecessary or unwise". Such a policy struck him as "bad enough" in an ethnically homogeneous country, but with regard to "national unity" it was virtually "suicidal" in South Africa, where its "diverse races" (a semantic typing which to Balmforth included Europeandescended groups) presented all kinds of potential internal conflicts. He was particularly concerned that because of "migration of population" conscripts could find themselves in situations where brother might be expected to fight brother and father against son (Balmforth s.a.:3).

\section{THE GREAT WAR AS A STIMULUS TO AN INTERNATIONAL PEACE PERSPECTIVE}

As far as Britons in the United Kingdom and overseas were concerned, the First World War stimulated both chauvinistic zeal to do combat and participation in peace movements. For Balmforth, of course, it was the latter. In June 1915, some eleven months after the outbreak of hostilities in Europe, he was one of the founders of the South African Peace and Arbitration Society, along with such Capetonians as Julia Solly (who in South African historiography is better known for her advocacy of women's suffrage) and Dr. Robert Forsyth, who represented part of the city in the Legislative Assembly. At a meeting held at the Young Men's Christian Association in Cape Town and presided over by Mrs. Solly, Balmforth moved a resolution that the Society be formed. Although not one of its officers in its early days, he served on its committee together with inter alia Mrs. Solly and J.D. Rheinallt Jones, who many years later would become known as the founder of the South African Institute of Race Relations (South African Peace \& Arbitration Society 1915-1916:1).

With Balmforth among its driving forces, the Society grew relatively rapidly, with its membership rising to 120 (fifty-two of whom resided in the Cape Peninsula) within a year. The fact that more than half lived elsewhere made "organised work and co-operation very difficult", in the words of the first annual report. However, the Society also reported "considerable sympathy and openness of mind in regard to our work" and gamely attempted to sway public opinion, partly through writing and distributing leaflets. It also nurtured close ties to such groups overseas as the National Peace Council in the United Kingdom, the Netherlands Anti-War Council, the World Alliance of Churches, the Society of Friends, or Quakers, and 
the Fellowship of Reconciliation (South African Peace \& Arbitration Society 1915-1916:2).

One of the Society's first leaflets, titled The True Basis of Peace, though published anonymously, bears the clear stamp of Balmforth's authorship. It is replete with phrases which already were or would become Leitmotive in his writing. Furthermore, ideationally the text reflects both Balmforth's commitment to Christianity of a liberal sort which foregrounded the brotherhood of humanity but also called for penitence while incorporating a conviction that human nature can still be perfected, despite the challenge the war was posing to this fundamental plank in the liberal creed.

Balmforth cited loosely Giuseppe Mazzini, the nineteenth-century liberal Italian political philosopher to whose works he would return repeatedly, that "only the human race as a whole, as a Unity, can attain to the highest and last goal of all human endeavour - the realisation of pure Humanity." To the socialist minister in Cape Town this meant that "the highest life, for nations as for individuals, can only be attained by co-operation, not by conflict, by the subordination of all individual and national self-seeking to the highest ends of life, and to the welfare of the whole." In a typically Balmforthean phrase, he assured readers that this was by no means a unique notion but that this unity was "taught and laboured for by all our greatest teachers" (The True Basis of Peace 1915:1).

Balmforth's commitment to Christianity and universal religion then came to the fore. He alluded to the apostle Paul in what appears to be a loose quotation of I Corinthians 12:11 to stress that "in all men and in all beings operates the one Spirit of God, given to all." He then quoted Jesus' charge in John 13 to the remnant of the Twelve after the departure of Judas Iscariot: "love one another even as I have loved you." Balmforth asserted on the basis of this text that "love, even though it leads to the Cross, is the Supreme power." He also cited James 4:1-3 to criticise humanity for turning away from this ideal and relate it to the contemporary campaign for peace: "Whence come wars and fightings among you? Come they not hence, even of the pleasures that war in your members? Ye kill and covet, and cannot obtain; ye fight and war; yet have not because ye ask not. Ye ask and receive not because ye are amiss" (The True Basis of Peace 1915:2-3).

To Balmforth, selfless love was essential not only to individuals but also countries if they wished to live in harmony with each other. Because they had "neglected these great spiritual truths and violated the laws of God" they had brought suffering on themselves. Consequently, there must be "a call to penitence". Not only all people, but "all the nations have sinned," and Balmforth did not except his homeland from that generalisation. He 
stressed that "even our own Empire has been engaged in no less than nine wars during the past years." The United Kingdom, no less than other nations, must "pass through the Valley of Humiliation and Penitence" (The True Basis of Peace 1915:3).

In practical, structural terms, Balmforth held forth a vision which would soon become a reality, albeit an ineffective one. "Some of the greatest jurists in the world have drawn up plans for the formation of an International Council and League of Peace for the prevention of future wars," he reported with unveiled hope. But harmony between nations could not spring solely from such an organisation. Rather,

When the [post-war] Settlement comes it needs that the Spirit of Christ shall sit at the Board, and the Spirit of Wisdom and Understanding in the high seats of Council, in order that we may win through to our goal of a righteous and enduring peace (The True Basis of Peace 1915:3).

\section{CRITICAL REACTION TO THE BULHOEK MASSACRE}

Much closer to home, Balmforth responded immediately and with outrage to the infamous "Bulhoek Massacre" of 24 May 1921. ${ }^{1}$ This had occurred when approximately 800 policemen killed possibly as many as 225 indigenous men, women, and children who, under the leadership of their self-styled "prophet" Enoch Mgijima, were part of a much larger throng that had illegally occupied land at Ntabelanga near Bulhoek in the Queenstown area of the eastern Cape province. His prophetic vision that the world would end in 1920 went unfulfilled, but conflicts with neighbouring farmers over encroachments on their land mounted, and after months of negotiations for the removal of the occupants proved fruitless, a quasimilitary action cleared the site with considerable loss of life. As the present

1 Within South Africa, the most accessible study of the Bulhoek massacre is the quadripartite series of articles by D.H. Makobe, who severely criticised the "Israelites" movement and its leader, Enoch Mgijima, as well as what Makobe regarded as a severely distorted interpretation of it which emanated from the History Workshop at the University of the Witwatersrand. See D.H. Makobe, "Confrontation with the Police: The Israelites of Enoch Mgijima and the Bulhoek Massacre of 24 May 1921", Militaria, XXVI, no. 1 (1996): 23-37; "The Price of Fanaticism: The Casualties of the Bulhoek Massacre", Militaria, XXVI, no. 1 (1996): 38-41; "Understanding the Bulhoek Massacre: Voices after the Massacre and Down the Years", Militaria, XXVI, no. 2 (1996): 98-105; and "Religious Fanatics That Became Political Heroes: The Historical Distortions of the Bulhoek Massacre", Militaria, XXVI, no. 2 (1996): 106-112. 
writer has argued elsewhere, responses by churchmen to the slaughter were varied. Many condemned it without reserve; others, not least in the Dutch Reformed Church, defended it as a regrettable but necessary evil (Hale 1994:68-84).

On 26 May, almost immediately after reading reports about the massacre in the Cape Town daily press, Balmforth vented his anger in a letter to the Cape Times. "The accounts of the shooting at Bullhoek read more like a battue than a battle," he declared. Balmforth found it especially disillusioning, because in a lecture delivered in London a few months earlier, he had asserted that although "native policy" in the Union of South Africa was imperfect, it was "more enlightened and humane" than race relations elsewhere in the world. Balmforth had pointed to the spate of lynchings in the United States of America and the mistreatment of Australian aborigines to illustrate the ostensible contrast. Turning to one of the most horrific incidents in the recent history of the British raj in India, he had also mentioned the massacre at the Sikh Golden Temple in Amritsar on 13 April 1919. The mass slayings at Bulhoek, Balmforth pronounced, compelled him to "take back my words" (Balmforth 1921:8).

The transplanted Unitarian also wrote about the matter at length in his denomination's weekly newspaper in England. In accordance with both his socialist principles and his commitment to rationalism in religion, Balmforth there laid the blame for the incident at the doors of both racial policies and what he regarded as irresponsible spirituality. "The natives, as a whole, have always regarded the Land Act of 1913 as a very unjust measure, dividing the land of the Union, as it did, in the proportion of seveneights to the European population (one and a quarter million) and oneeighth to the native population (4 and a half millions)," he explained. "The allocation of the respective areas has undoubtedly caused great hardship amongst natives in various part[s] of the Union." But in this particular case what to Balmforth was a perverse departure from Christianity had proven disastrous. He described Mgijima as "a somewhat fanatical leader" who had built "a rude tent 'tabernacle"' at Bulhoek and organised his "Israelites" as "a new sect". Their belief in "the almost immediate second coming of Christ and the dissolution of the present world-order", Balmforth believed, had made Mgijima's followers "somewhat careless of earthly consequences". The sanguinary calamity confirmed Balmforth's views about "the curious combination of moral effects which are often the result of religious fanaticism - a raising of the moral and spiritual life within the circle of the sect, and a lowering of it in the shape of bigotry, intolerance, 
and overbearingness, to those outside it, The [sic] 'chosen people' over again!"2

Balmforth did not, of course, condone the use of lethal force to remove the recalcitrant Israelites. Rather than using "harsh militarist tactics" against the "simple-minded fanatical natives" and to arrest "two or three half-crazy leaders" at Bulhoek, the South African government should have recalled the effectiveness of the "enlightened methods employed by Livingstone and Moffat" in the nineteenth century. Balmforth feared that the "dark undercurrents of unreasoning prejudice, passion, hatred, and revenge which are going to be the brewing of the hell-broth of the next racial war" and which he found described in such books as W.E.B. Du Bois's Darkwater and Theodore Stoddard's The Rising Tide of Color Against White World-Supremacy, both of which had been published in the United States of America the previous year, were proliferating in South Africa. It all seemed to be part of an international mentality which boded ill for the future:

Into those currents we are throwing our Amritsars, our Jewish pogroms, our Egyptian repressions, our Irish reprisals, our Bullhoeks, and our American lynchings, (and) if we have not the brains to find other remedies than these then the future of civilization is dark indeed (Balmforth 1921:405-406).

The government's armed intervention at Bulhoek, thought Balmforth, did not augur well for the future of South Africa and underscored fundamental flaws in the country's educational policies. "Militarism, with its contempt for human life, is rampant in our schools," he complained, "and boys of 15 or 16, after being taught the Sermon on the Mount, are trained in the art and science of maiming and wounding their fellow-creatures and killing them at need." At the same time, the curricula for white youth did not make room for "studying native languages, customs, and institutions." Balmforth also interpreted the massacre in terms of a larger class struggle: "We are too busy making money, and having made it the whole tendency of our civilisation leads us to defend it and protect ourselves from our fears by all the latest scientific instruments and implements - machine-guns, tanks, bombs, aeroplanes, and what not!" He concluded presciently:

2 Ramsden Balmforth, "The Tragedy at Bullhoek", The Inquirer, no. 4126 (new series: 1229) (30 July 1921), pp. 405-406. In a brief comment following the text of Balmforth's letter which was published in abridged form, the editor of the Cape Times explained that some parts of that document were not being printed and accused Balmforth of being "not only ill-informed but mischievous". The full version of the letter appeared in The Inquirer, to which reference is made here. 
To this pass we have come, and by our fruits posterity will know us. Truly, the present generation seems to have little idea what a load of retribution is piling up for our children and our children's children (Balmforth 1921).

Balmforth's South African Peace and Arbitration Society reacted critically to the massacre. Shortly thereafter, he presided at a wellattended public hearing in the Cape Town City Hall. Some unidentified speakers commended the South African government for its "patience and forbearance in the early part of the dispute", but several reportedly emphasised that unspecified other methods should have been employed before the police opened fire with machine guns and artillery. Among these non-violent strategies,

the influence of the leading missionary organizations might have been invoked, (and) as the dispute was partly of a religious nature the heads of the churches might have been asked to use their influence ... (Balmforth 1922: 83-84).

\section{RESPONDING TO INTERNATIONAL TENSIONS IN THE 1930S}

The crescendo of tension in European international relations during the 1930s greatly concerned Balmforth, who visited both the United Kingdom and continental Europe at least twice during that decade. He had been gratified to witness the establishment of the League of Nations but, like countless other observers, found its lack of effectiveness disturbing. Unlike many thousands of members of the League of Nations Union in his homeland, however, Balmforth did not become disillusioned with the organisation and continued to believe that it could serve as an instrument for averting war.

In Cape Town, Balmforth continued to minister to his church in Hout Street, preaching nearly every Sunday evening during the 1930s while also writing extensively. Current events, especially in Europe, left their mark on his homiletics. As had frequently been the case in the past, he sometimes gave short series of sermons, or "discourses" as he preferred to call them, and at times these continued to be based on works of imaginative literature. To cite but one example from the early years of the decade, on 5 July 1931 Balmforth preached on Erich Maria Remarque's recently published sequel to his renowned novel All Quiet on the Western Front (originally Im Westen Nichts Neues), Der Weg zurück (Free Protestant (Unitarian) Church 1931:2). 
This German pacifist's works, which would be banned in the Third Reich, inspired many other writers of like mind.

As the decade progressed, Balmforth saw little reason for optimism that Europe or the world generally would attain international political harmony, notwithstanding the advance of pacifist movements in several countries, including the United Kingdom. In his Christmas message for 1933, some nine months after the accession of Hitler and the National Socialist German Workers' Party to power in Germany, he concentrated on the bleakness of life in the slums of Cape Town and on the Cape Flats, "where thousands are living under conditions which are an offence to decency, to health, and to civilisation". Reasons for pessimism were not merely local. "If we look further afield the outlook is equally black," Balmforth lamented. "Never since the war (of 1914-1918) has there been such an outburst of national and racial animosities as during the past year. The Disarmament Conference, which opened with such high hopes, has been suspended. The League of Nations is in danger. The international spirit among both the great and the smaller nations, has been weakened, and fear and suspicion have taken its place." The general nostrum which Balmforth prescribed was that, at least in "Christian nations", "the Christ-spirit must be "born within' and so order and guide our outward and collective life" (Free Protestant (Unitarian) Church 1934:3).

\section{RESPONDING TO MUSSOLINI'S INVASION OF ABYSSINIA}

The invasion of Abyssinia by Mussolini's forces in 1935 and 1936, and especially the ineffectiveness of the League of Nations in preventing that aggressive act, caused headaches for pacifists of various hues and nonpacifists alike. It became increasingly obvious to many observers in one country after another that the international community lacked both the will and the organisational means to halt a determinedly aggressive foreign policy. In distant Cape Town, however, Balmforth soldiered on in his campaign for idealistic solutions based on his liberal religious views. His response to the Abyssinian crisis came to the fore in a sermon preached on 26 January 1936, i.e. while hostilities between Italy and Abyssinia were escalating and after the imposition of League sanctions against Italy but several months before the conquest of the Abyssianian capital, Addis Ababa. The address is particularly noteworthy for an understanding of Balmforth's pacifism because it foreshadowed his subsequent rejection of absolute rejection of armed intervention and underscored his conviction 
that the League of Nations could become an effective instrument for maintaining international peace.

True to his latitudinarian religious convictions, Balmforth began with quotations from both Buddhist and Christian scriptures. From the Dhammapada, he cited: "Hatred does not cease by hatred at any time: hatred ceases by love." From the eighteenth chapter of the Gospel of Matthew, Balmforth quoted Jesus's locus classicus regarding the resolution of conflicts between Christians: "If thy brother sin against thee, go, shew him his fault between thee and him alone: if he refuse to hear thee, tell it unto the congregation." He added in brackets, "In modern phrase, the congregation of the League at Geneva" (Balmforth 1936:3).

Balmforth assured his congregation that he was not "an enemy of Italy". Indeed, that nation's cultural legacy, he explained, had contributed mightily to Western civilisation, which he regarded as to a great extent the expression of the divine spirit. Italian history featured men like Dante, Giotto, Leonardo da Vinci, Savonarola, and Garibaldi. Under Mussolini, however, Italy had gone astray; it had become a temple for the glorification of a Nietzschean will to power, militarism, and the state. II Duce, as described from the pulpit of the Unitarian church in Hout Street, was "a Nationalist with an Imperialistic bent". In diametrical opposition to Balmforth's liberal emphasis on the development of the individual, Mussolini "believes that the individual must be entirely subordinate to the State" and that

man is a fighting animal, that war is a glorious thing, that nations must make themselves so strong that other nations dare not attack them, and that they have then the right to be both the judge and jury in their own cause (Balmforth 1936:1, 4-5).

Rather than blindly following Mussolini and others whose thirst for war made them "a danger to civilisation" who "should be interned in a mental hospital", Balmforth suggested that the Italians should take their cues from one of their nineteenth-century heroes, Giuseppe Mazzini. That liberal Italian political philopsopher had offered a
deeper and saner mysticism [than Mussolini] which takes the whole of humanity into its purview, and which insists that in the great family of nations the rights of each individual nation, while receiving due recognition, must be subordinate to the well-being of the whole (Balmforth 1936:5-6).

In at least one respect, Balmforth's construction of Mazzini is incomplete and surprising. That Italian patriot had not rejected violence to nearly the same extent as did the Unitarian in Cape Town; indeed, he led 
armed uprisings against some of the Italian principalities. Nevertheless, Balmforth believed that "the wider love of humanity" which Mazzini had espoused could inspire the troubled world of the 1930s.

How? For the answer, Balmforth turned to the Harvard philosopher Josiah Royce, more specifically his Gifford Lectures delivered at the University of Aberdeen between 1898 and 1900 and published as The World and the Individual, and the essay of 1916, "War and Insurance". In the latter piece, Balmforth announced, Royce had "showed how all the healthy loyalties of men culminate in ... 'the beloved community' of mankind - as taught by all the great teachers, from Confucius, Buddha, Jesus, St. Paul, and St. Francis, down to Mahatma Gandhi and our own poet Shelley". He found convincing the Harvard idealist's proposal for a league of nations which would promote an international sense of loyalty, a "world-patriotism" and seek to counter war-mongering through "insurance". As refracted through the prism of Balmforth's summary, the already established practice of distributing risk against e.g. maritime disasters, earthquakes, and crop failures could be adapted to international relations through the creation of an international insurance organisation which would "insure its nation-members against many of the evils of actual war, and would directly tend to prevent war". This latter goal could be promoted by adopting a policy that no compensation would be granted to any nation found to have "committed the first act of war" (Balmforth 1936:7-9). In retrospect, it seems at least arguable that Balmforth naively underestimated the ability of nations to reach a consensus about the causes of any particular war and their ability to enforce the principles which supposedly would guide such an organisation. He also failed to deal with the obvious problem of an aggressive nation successfully imposing its will on the organisation itself, thereby rendering the whole exercise moot.

Balmforth had not yet lost faith in international sanctions as an instrument of deterring war. His discussion of this revealed that at least as early as $\mathbf{1 9 3 6}$ he was explicitly distancing himself from absolute pacifism, as he would further do in 1940, a matter to which we shall turn shortly. Balmforth assured readers that "undoubtedly" the League of Nations could effectively impose them in accordance with Article XVI of its Covenant. In harmony with a proposal made by one of his Fabian heroes, George Bernard Shaw, in 1929, he favoured a strengthening of the League. That would be immeasurably preferable to abandoning it, as many people (including erstwhile members of the League of Nations Union in the United Kingdom) were doing. Balmforth insisted that 
we must not allow the ramrod of Totalitarianism to jam its delicate machinery or to interfere with its international work and aims (Balmforth 1936:9, 12-13).

What Balmforth could not predict, of course, was that Italy's withdrawal from the League of Nations in December 1937 would further frustrate the vision of using that body as a means of disarming international conflicts.

In the same section of Humanity at the Cross-Roads, Balmforth revealed that he had pitched his tent in the camp of what would later be called "pacificism" rather than that of absolute pacifism. The absolute position was not a realistic one for governments to assume, regardless of how tenable it might be for some individuals. "Our extreme pacifist friends must remember that a Government has not only to teach, it has to govern, and if it neglects to govern, both teaching and government may go by the board," he chided. A graphic and unmistakable bit of symbolism served Balmforth's rhetorical strategy:

If, for example, a body of gangsters began to parade the streets with machine-guns, levying blackmail on honest merchants, any Government which could temporarily paralyse them by one or two electric shocks would be quite justified in doing so, and if one or two gangsters died in the process, that is their look-out (Balmforth 1936:9).

\section{MORAL RELATIVISM IN THE CAMPAIGN AGAINST HITLER}

The ascendancy of the National Socialist German Workers' Party, or "Nazis", to power in 1933 and the subsequent remilitarisation of Germany, followed by that country's expansionist foreign policy gave many pacifists throughout Europe headaches. As the decade of the 1930s progressed, public opinion in the United Kingdom and elsewhere was gradually resigned to the virtual inevitability of another major war on the continent. The British peace movement remained strong throughout the decade, but Hitler's occupation of the Sudetenland in 1938 and invasion of Poland in September 1939 posed an unprecedented challenge to pacifist ideals. Many adherents of the movement, including a considerable number of clergymen, felt compelled to compromise their principles on the grounds that the danger of wholesale German aggression as the Wehrmacht waged one Blitzkrieg after another with enormous loss of human life rendered peaceful means of international conflict resolution entirely ineffective. 
Then retired from the ministry but still residing in suburban Cape Town and bearing the title "minister emeritus", Balmforth continued to write about public issues, including international politics. In June 1940, after Hitler's forces had invaded and gained control over Denmark, Norway, the Netherlands, Belgium, and France, Balmforth penned a booklet in which he presented his apologia. Titled Above the Battle - Man's Unconquerable Mind, it was intended to be read by fellow ministers, "especially those of our Liberal household of faith in Great Britain, the British Dominions, and throughout Europe and America". In a five-page preface, he announced that he had been a "pacifist" since his youth. Keenly aware that pacifism was not a unitary ethical position, Balmforth explained that his was not of a "quietist" or "mystic" type associated with Tolstoy, Gandhi, and Quakers generally, but rather that he rejected war "on rational grounds" which made him hate it as "an evil thing". His rationality necessitated that he differentiate between "aggressive and defensive war". Accordingly, Balmforth postulated, "The use of force in the protection of Law and of human life is obviously necessary." He criticised the absolute pacifist Tolstoy, who had "carried his theory of non-resistance to unreasonable length, as his biographer, Aymler Maude, frankly admitted." Furthermore, Balmforth did not believe that one could unconditionally rely on what Christianity had traditionally regarded as the written Word of God for guidance in the resolution of conflicts. His selective attitude towards the moral legitimacy of Biblical texts came to the fore in his brief discussion of the notorious verse Psalm 137:9 ("Happy is the one who seizes your infants and dashes them against the rocks"). Instead of that vengeful text from the Babylonian captivity, Balmforth urged readers to follow the "inspired words" of Isaiah 53 or Matthew 18 as their lodestar. He noted that his unwillingness to adhere to absolute pacifism was by no means an isolated case; such luminaries as Bertrand Russell, Romain Rolland, and Hugh Martin who had been pacifists in the First World War had now

declared that Nazi-ism and Fascism, with their deification of brute force, must be defeated if civilisation and true religion are to survive (Balmforth 1940:1-5).

Balmforth's argument for actively opposing German militarism stems remarkably from his rationalistic view of human civilisation as it comes to expression in inter alia world religions, especially Christianity. Taking one of his rhetorical cues from Wordsworth's phrase "man's unconquerable mind" in the poem "To Toussaint L'Ouverture", he described Germany as having challenged it "throughout the whole civilised world" and therewith "in that spiritual world which exists above the battle, and which, in the ultimate resort, decides the destinies of nations". The "spiritual world" to which Balmforth referred was what had been developed by the human 
mind "under the guidance and the laws of a Supreme spiritual power". He presented a syllabus errorum which Germany had committed:

The Nazi philosophy is based on the Deification of brute force and the denial of the supremacy of Reason; on a theory of State infallibility based on racial discrimination and racial prejudice, as against the belief in human brotherhood and the equal right of every man and every nation to the fullest opportunities for selfdevelopment, consonant with like opportunities for others; on the denial of freedom of thought and speech, and the imprisonment, persecution or exile, of those who do not accept the Nazi philosophy of the State; the violation of the rights of personality to such an extent that men come to be regarded as mere automata or cogs in a vast military machine, trained and drilled to servile habits of socalled discipline; and, worse than all, the poisoning of the soul of the child and the dwarfing and narrowing of its mind and heart by the teaching of these odious doctrines in the schools, thus shutting out from its mind those humanising influences of civilisation and culture which have been slowly built up through centuries of effort by man's unconquerable soul (Balmforth 1940:6).

As part of his rhetorical strategy, the English South African Balmforth juxtaposed the Nazi advocacy of compulsion and brainwashing with his image of the post-imperial Commonwealth of Nations, which embodied "great traditions, a great history, [and] a great literature". Ever since its creation by an act of Parliament in the early 1930s, he insisted, the Commonwealth had propagated a liberal spirit which nurtured human development. Precisely that, Balmforth believed, lay in the balance when one was weighing the decision to oppose Hitler.

It is this idea of the Commonwealth, as against domination by brute force, which is the animating spirit of this great struggle (Balmforth 1940:6-7).

As a long-time minister of religion, Balmforth included a section on religious dimensions in the conflict. He acknowledged that the war was "a struggle for Christianity" but averred that it was "something more than that", namely "a struggle for the eternal verities of Religion itself". Those timeless truths, Balmforth generalised, antedated the Christian faith and were part of human religion as a global phenomenon which must be preserved. They had come to

expression in all the great religion and were voiced and strengthened by the great Hebrew prophets, by Buddha, by Confucius, by Stoic, Platonic, and other great thinkers, and especially and above all, by Jesus of Nazareth (Balmforth 1940:7). 
However inevitable and excusable many like-minded peace advocates in the Union of South Africa and the United Kingdom may have regarded Balmforth's ostensible changing of his spots, it bitterly disappointed at least one of his erstwhile allies in the socialist struggle. Wilfrid H. Harrison, a fellow Englishman who had emigrated to South Africa some five years after Balmforth had stepped ashore in Cape Town, found this apparent volte-face sufficiently disillusioning to describe it at length in his Memoirs of a Socialist in South Africa 1903-1947. The two men had campaigned arm-in-arm, if only sporadically, for nearly four decades in support of various causes. Like his Unitarian friend, the self-styled agnostic Harrison had been active in the Peace and Arbitration Society during the First World War. He wrote retrospectively that Balmforth, Robert Forsyth, and Julia Solly had been "the most lovable trio of humanitarians one could find in Cape Town". But in the end at least Balmforth and Forsyth, from his perspective, had betrayed their previously shared ideal.

They, who wrote and talked and often came to the court in my defence against the popular cry in the previous war, [Harrison lamented,] believe in guns, bombs and human vengence [sic] in this war (Harrison 1947:141).

Writing in 1947, Harrison recalled that during the Second World War he had had "considerable correspondence" with Balmforth about the ethical problem Hitler and the conflagration in general had posed for absolute pacifists. "As to the war, it is too ghastly for words," the retired Unitarian had observed. Yet the very ghastliness unleashed by German expansionism had prompted him in the end to take a different stance. "We must discriminate between aggressive and defensive war." Shifting his argument to an ad hominem level, he chided Harrison, "Don't tell me that you would not defend your wife - even with a hatchet or bayonet if needs be - against a brutal or fanatical murderer." The international situation in Europe was analogous, just on a vastly larger and even more violent scale. "Hitler is deliberately and wantonly sacrificing millions of lives on that Russian front, and what for?" he asked rhetorically (Harrison 1947:141142). Harrison could not deny the core veracity of Balmforth's argument. The sole difference between himself and Balmforth, he concluded, was that Balmforth had begun to

discriminate between the aggressive and the defensive parties in war, whereas I cannot discriminate, so vast and so complicated has war diplomacy become (Harrison 1947:141-142). 


\section{CONCLUSION}

The disillusioned Harrison's comments illustrate lucidly how an inadequate perception of "pacifism" beclouded Balmforth's more nuanced views and are little more than a crassly reductionist caricature of this Unitarian's positions. Research into the history of South African Christians' varying attitudes to military conscription, armed resistance to international aggression, and related matters is still in its early stages, generally speaking. As it advances, scholars who engage in it would do well to avail themselves of Ceadel's categories and perhaps further refine those of "pacifism" and "pacificism". The interplay of multiple theological, ideological, and other determinants in the culturally pluralistic crucible of South Africa requires us to bear in mind that for a variety of reasons Christians, no less than other people, often had qualified rather than categorical notions about the defensibility of the use of military force. Although Balmforth stood theologically quite far from most other ministers in South Africa, for four decades he interacted with many of them and with a broad spectrum of lay people, not least in his efforts to promote peace at home and abroad. He merits considerably more scholarly attention than he has received.

\section{BIBLIOGRAPHY}

BALMFORTH, R.

1940. Above the Battle - Man's Unconquerable Mind. Cape Town: C. Blackshaw \& Sons (Pty.) Ltd.

1936. Humanity at the Cross-Roads. Cape Town: C. Blackshaw \& Sons (Pty.) Ltd.

n.d. The War and the Coming Peace. An Appeal to Sober-Minded People. Cape Town: O. Hartmann, City Printing Works.

BIRN, D S.

1981. The League of Nations Union. Oxford: Clarendon Press.

Ceadel, M.

1980. Pacifism in Britain 1914-1945: The Defining of a Faith. Oxford: Clarendon Press.

Free Protestant (Unitarian) Church, Monthly Calendar.

1942. "Memorial Service", Free Protestant (Unitarian Church, Monthly Calendar, Vol . 22, no. 2 (February 1942), p. 5.

1931. Church Services, Free Protestant (Unitarian) Church, Monthly Calendar, XI, no. 6 (1931), p. 2. 
HaLe, F.

1994. Fear and Support of an African Independent Church: Reactions to the Bulhoek Massacre of 1921. Fides et Historia 26(1): 68-84.

2001. A Nonconformist Waging Peace: The Foundations of Ramsden Balmforth's Initiatives in the Second Anglo-Boer War. Studia Historiae Ecclesiasticae 27(2): 97-112.

HARRISON, W.H.

1947. Memoirs of a Socialist in South Africa 1903-1947. Cape Town: South African Stewart Printing Co. (Pty.).

Maкoвe, D.H.

1996a. Confrontation with the Police: The Israelites of Enoch Mgijima and the Bulhoek Massacre of 24 May 1921. Militaria 26(1):23-37.

1996b. The Price of Fanaticism: The Casualties of the Bulhoek Massacre, Militaria 26(1):38-41.

1996c. Religious Fanatics That Became Political Heroes: The Historical Distortions of the Bulhoek Massacre, Militaria 26(2):106-112.

1996d. Understanding the Bulhoek Massacre: Voices after the Massacre and Down the Years, Militaria 26(2):98-105.

TAYLOR, A.J.P.

1915. The True Basis of Peace. Cape Town, City Printing Works.

1957. The Trouble Makers. Dissent over Foreign Policy 1792-1939. London: Hamish Hamilton.

Keywords

Ramsden Balmforth

Pacificism

Pacifism

Unitarian

Conscription
Trefwoorde

Ramsden Balmforth

Pasifisme

Pasifisisme

Unitariër

Militere diensplig 